\title{
Effect of silver nanoparticles on water quality and phytoplankton communities in fresh waterbody
}

\author{
Anh hương của vật liệu nano bạc đến chất lượng nước và quần xã thực vật phù \\ du trong thủ vục nước ngot \\ Research article
}

Tran Thi Thu Huong ${ }^{1,2}$; Duong Thi Thuy ${ }^{2,3}$; Nguyễn Trung Kien ${ }^{3}$, Le Thi Phuong Quynh ${ }^{4}$, Nguyen Duc Dien ${ }^{5}$, Pham Thi Dau ${ }^{6}$, Nguyen Hoai Chau ${ }^{3}$

${ }^{I}$ Faculty of Environment, Hanoi University of Mining and Geology (HUMG), Ha Noi, Viet Nam; ${ }^{2}$ Graduate University of Science and Technology, Vietnam Academy of Science and Technology (VAST), ${ }^{3}$ Institute of Environmental Technology, VAST, Ha Noi, Viet Nam; ${ }^{4}$ Institute of Natural Products Chemistry, VAST; ${ }^{5}$ School of Chemistry, Biology and Environment, Vinh University, Faculty of Biology, VNU University of Science, Ha Noi, Vietnam

\begin{abstract}
This study aims to investigate the potential effects of environmental variables and the toxicity of nanosilver colloids synthesized by chemical reduction method on growth and development of phytoplankton community (the Microcystis genus dominance) in the eutrophication Tien lake water, Hanoi city, Vietnam. The variables analyzed including: physical ( $\mathrm{pH}$ and Turbidity), chemical (content of $\mathrm{NH}_{4}{ }^{+}, \mathrm{PO}_{4}{ }^{3-}$ and silver metal), biological (content of Chlorophyll-a, cell density). The characteristic of nanomaterial was confirmed by using UV-visible spectrophotometer, TEM and HR-TEM methods. The obtained silver nanoparticles (AgNPs) showed that their spherical form and uniform size varied from 10 to $15 \mathrm{~nm}$. The experimental results showed that the samples treated with AgNPs inhibition on growth against $M$. aeruginosa at concentration $1 \mathrm{mg} / 1$ after 8 days. The content of silver in aquarium water decreased from $1 \mathrm{mg} / 1$ (D0) to $0.8 \mathrm{mg} / 1$ (D8). The contents of chlorophyll-a of phytoplankton community, including Microcystis genus in samples exposed with $\mathrm{AgNPs}$ were declined from $11.27 \pm 0.56 \mu \mathrm{g} / \mathrm{L}$ (D0) to $1.98 \pm 0.37 \mu \mathrm{g} / \mathrm{L}$ (D8) . The environmental variables such as: $\mathrm{pH}$, temperature, dissolved oxygen, turbidity, ammonium, phosphate...in the experiment were below the limit of the Vietnam Standard 08:2015/MONRE for surface water quality.
\end{abstract}

Muc đích của nghiên cứu này là khảo sát ảnh huởng của vật liệu nano bạc tổng hợp bằng phuơng pháp khử hóa học đến sinh truởng và phát triển của quần xã thực vật nổi (chủ yếu là chi Microcystis) trong nước hồ Tiền phú dương, tại Hà Nội, Việt Nam. Các thông số phân tích bao gồm: thủy lý ( $\mathrm{pH}$ và độ đuc), hóa học (hàm luợng amoni, photphat và hàm luợng bạc kim loại), sinh học (hàm lương chất diệp luc, mật độ tế bào). Đặc trung của vật liệu được xác định bằng các phuong pháp quang phổ UV-VIS, TEM và HR-TEM. Vật liệu nano bạc có dạng hình cầu, kich thuớc đồng nhất trong khoảng 10-15nm. Kết quả thử nghiệm sau 8 ngày cho thấy các mẫu có bổ sung vật liệu nano bạc úc chế sinh truởng đối với vi khuẩn lam M. aeruginosa ở nồng độ $1 \mathrm{mg} / \mathrm{l}$. Hàm luợng bạc kim loại giảm tù̀ $1 \mathrm{mg} / \mathrm{l}$ (ngày đầu tiên) xuống còn $0.8 \mathrm{mg} / \mathrm{l}$ (vào ngày cuối cùng). Sinh khối thực vật nổi trong đó có chi Microcystis trong mẫu xử lý với AgNPs đã giảm tuơng úng tù $11.27 \pm 0.56$ $\mu \mathrm{g} / \mathrm{L}$ (ngày đầu tiên, D0) xuống $1.98 \pm 0.37 \mu \mathrm{g} / \mathrm{L}$ (ngày cuối cùng, D8). Các thông số môi truờng của nước hồ đều nằm duới giới hạn cho phép của QCVN 08:2015/BTNMT đối với chất luợng nước mạtt.

Keywords: Cyanobacteria, Microcystis aeruginosa, effect, nanoparticles

\section{Introduction}


from condominiums and urban areas, which contributes significantly to the amount of nutrients (mainly $\mathrm{N}$ and $\mathrm{P}$ ) in the receiving resource systems. This process contributes significantly to improve the quality of human life, but also makes the problem of environmental pollution more difficult, especially the eutrophication in fresh waterbodies. Eutrophication is an ecological term used to describe the over-enrichment of inorganic nutrients in water, typically nitrate and phosphate salts lead to excessive growth of aquatic organisms in which the majority of Cyanobacteria species are potentially toxic (Smith, 1983; Lennevey, 2017). The initial cause was identified as a loss of nutrient balance in the ecosystem's input, thus creating a competitive advantage for one species compared to other organisms in the ecosystem. In recent years, harmful algal blooms have been occurring in both saltwater (red tide) and freshwater (water blooming) both in frequency, intensity and duration (Codd, 1997; Beversdorf et al 2015; Paerl, 2014; Wang, et al., 2016; Boopathi, et al., 2014; Drobac, 2013).

Until now, about 100 species of freshwater cyanobacteria have been discovered in 40 genera of which Microcystis, Anabaena, Aphanizomenon, Oscillatoria, Nostoc and Cylindrospermopsis are the most frequently encountered in water blooms (Dang et al. 2014). Microcystis genus is the most common cyanobacteria, it is toxic to humans, animals and other aquatic organisms. This is one of the main cyanobacteria cause to water blooming. Microcystis genus is a group of thousands of individual cells, ranging in size from 2 to $6 \mu \mathrm{m}$ and each cell contains an stomata, extensively distributed from nutrient-poor to brackish water and seawater. They pose a serious threat to the quality of water resources, change aquatic ecosystems and cause water pollution problems such as "water blooming" around the world (Blahoslav et al., 2012). Therefore, prevention and reduction of the rapid development of cyanobacteria are important environmental issues.

Currently, nanotechnology is widely used in the removal of pollutants in water. The nanoscale materials tend to used in place of traditional chemicals have been observed in several countries around the world in recent years. Nanomaterials exist in the form of activated materials such as carbon, cellulose and aluminium with carriers such as zeolite, bentonite and compounds containing $\mathrm{Fe}$ that can be used in aquaculture to remove ammonia, nitrite and nitrate (Blahoslav, 2012; Drabkova, 2007). Because of many advantage features and high applicability over traditional materials so the production of NPs indicates that quantities produced globally will likely increase steadily. Application of nanomaterials to treat water pollution especially toxic algae treatment in Viet Nam and over the world has received much attention and obtained certain results (Gubbin et al., 2011). Silver nanoparticles with unique antibacterial properties have been used in many fields such as molecular diagnostics, medical, catalysing, electronics... and recently applied in the treatment of environmental pollution (Skamaran, 2012). There are some of documents reported about effect of silver nanoparticles on bacterial, fungal, and mammalian cells but the impact of silver nanoparticles on algal growth has not been studied extensively. In our study, we have selected the Tien lake water to conduct at laboratory scale to in- vestigate the potential effects of environmental variables and the toxicity of silver material synthesized by chemical reduction method on growth and development of phytoplankton community (the Microcystis genus dominance) in the eutrophication Tien lake water, Hanoi city, Vietnam.

\section{Material and methods}

\subsection{Experiment setup}

Experimental setup is similar to the experiment with copper nanoparticles published by the authors (Tran TTH, et al., 2016). The experiment was performed in aquarium tank containing approximately 10 litters of water collected from Tien Lake. Silver nanoparticles (AgNPs) was added in aquariums with the concentration of $1 \mathrm{ppm}$. The experiment was performed in triplicate. The experiment was conducted in 14 days under room conditions without aeration process. During the experiment, physical variables ( $\mathrm{pH}$, Turbidity) chemical variables $\left(\mathrm{NH}_{4}{ }^{+}, \mathrm{PO}_{4}{ }^{3-}\right.$ and concentration copper) and phytoplankton biomass (Chlorophyll a) and density of cell were monitored at D0, 1, 2, $3,4,8$ days.

\subsection{Chemical synthesis of silver nanoparticles}

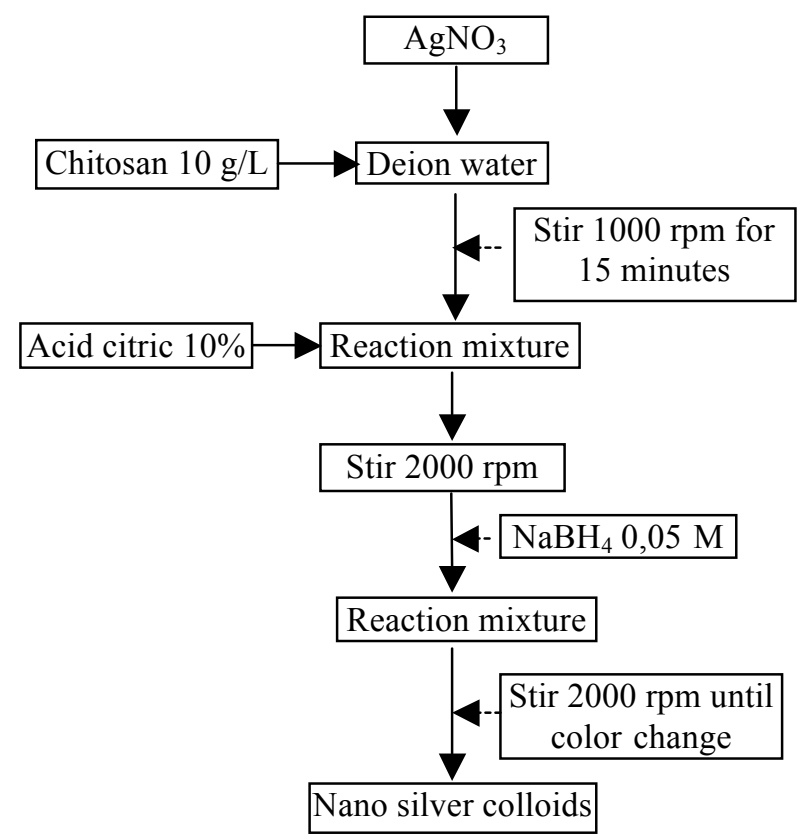

Figure 1. Overall procedure for preparing nanosilver colloids by chemical reduction method

The silver nanoparticles were synthesized by a chemical reduction method at room temperature (overall procedure showed in figure 1). Silver nitrate, $\mathrm{AgNO}_{3}(>99 \%)$ as the precursor for the formation of $\mathrm{Ag}$ nanoparticles was purchased from the Merck Chemical Reagent Co. Sodium borohydride, $\mathrm{NaBH}_{4} 98 \%$ purity used as the main reducing agent was purchased from the Scharlab (Sentmenat, Barcelona, Spain). Preparation of the stock solutions of $\mathrm{AgNO}_{3}$, citric acid $1000 \mathrm{ppm}$ and $\mathrm{NaBH}_{4}$ 0.05M with deionic water. The $1000 \mathrm{ppm}$ chitosan solution is dissolved in $10 \%$ acetic acid solution. To gain $100 \mathrm{ppm}$ silver 
nanoparticles, add the $200 \mathrm{~mL}$ of deionized water into glass beaker $(500 \mathrm{~mL})$ containing $\mathrm{AgNO}_{3}$ and chitosan stabilizer. The mixture is stirred with IKA RW 20 digital stirrer with speed $1000 \mathrm{rpm}$ for 15 minutes. Next, the citric acid solution is slowly added to the mixture according to the survey ratios. Then, slowly drop the solution $\mathrm{NaBH}_{4}$ $0.05 \mathrm{M}$ into the mixture and continue to stir with $2000 \mathrm{rpm}$ until the solution turns yellow. The obtained nanosilver colloids in the concentration $300 \mathrm{ppm}$ were stored in hermetic flasks, dark colour.

Morphology and size of the nanoparticles were examined using a transmission electron microscope (TEM) (JEOLJEM1010, Japan), a high-resolution transmission electron microscope (HR-TEM) (JEM 2100, Japan) and the UVVIS 2450 (Shimadzu, Japan) methods.

\subsection{Effect of nanoparticles on natural phyto- plankton assemblage}

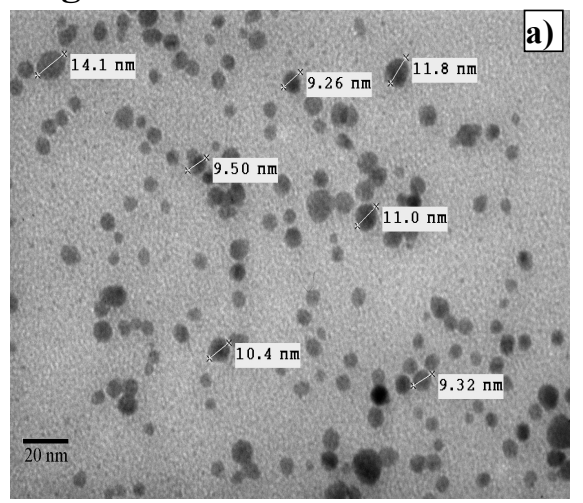

These methods for assessment of effect of nanoparticles on natural phytoplankton assemblage such as: Cell counting by optical microscopy, Ammonium $\left(\mathrm{NH}_{4}^{+}\right)$and Phosphate $\left(\mathrm{PO}_{4}{ }^{3-}\right)$ measurement and the content of silver metal is similar to the experiment with copper nanoparticles published by the authors (Tran et al, 2016).

\subsection{Statistical analysis}

All experiments were done in triplicate and the data were calculated as mean \pm SD (standard deviation) and drawn by the software GraphPad Prism 6. Statistical significance was accepted at a level of $\mathrm{p}<0.05$.

\section{Results and discussion}

\subsection{Characteristics of silver nanoparticles}

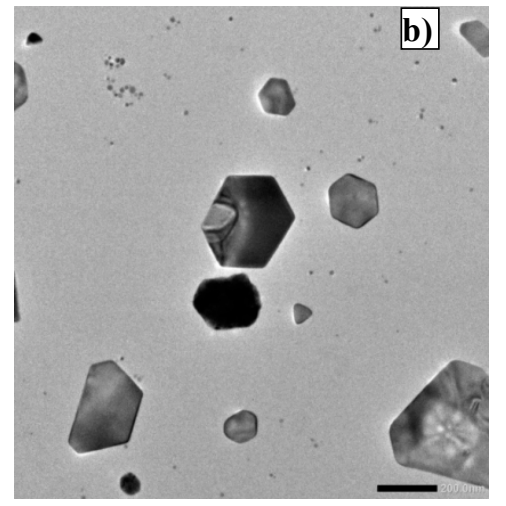

Figure 2. TEM (a) and HR-TEM (b) images of nanosilver colloids synthesized by chemical reduction method

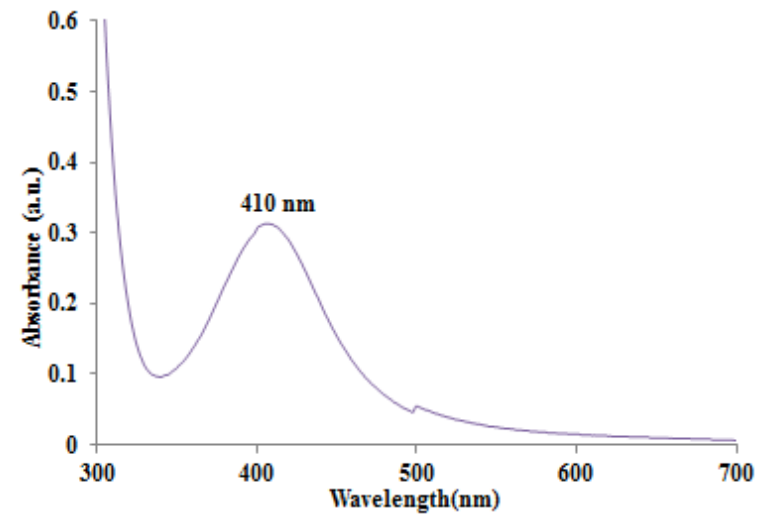

Figure 3. UV-VIS absorption spectrum of nanosilver colloid synthesized by chemical reduction method

Figure 2 and 3 shows the UV-Vis spectra, TEM and HRTEM images of nanosilver colloid prepared by chemical reduction method under the following optimum reaction parameters: $\left[\mathrm{NaBH}_{4}\right] /\left[\mathrm{AgNO}_{3}\right]=1: 4$; [chitosan] $=300$ $\mathrm{mg} / \mathrm{L} ;$ [citric acid] $=3.0 \mathrm{mg} / \mathrm{L}$ and reductant drop rate $=$ $10 \mathrm{drops} / \mathrm{min}$. Figure $2 \mathrm{a}$ shows that the size of the synthesized silver is in the range of nanometre. The particles have spherical form and uniform size about 10-15 $\mathrm{nm}$. The silver nanoparticle structure at the optimum ratio indicates that they have a hexagonal crystal structure typical of metallic nanoparticles (Figure $2 b$ ). The results of the HR-TEM imaging showed that the crystals are oriented along the Face centered cubic structure (Fcc) and matched the results of the previously published study (Kumar, 2000; Siwach et al., 2008). The UV-Vis absorption spectra of these nanosilver colloids revealed a high intense Plasmon absorption peak near $410 \mathrm{~nm}$. Silver nanoparticles have a surface Plasmon absorption between $400 \mathrm{~nm}$ and $450 \mathrm{~nm}$ as reported in the previous literatures (Kumar, 2000; Siwachet al., 2008; Mithun, 2017). Optical absorption spectra of metal nanoparticles are dominated by Plasmon resonance surfaces. The position and shape of the absorption spectrum of the nanoparticles depends strongly on particle size, dielectric constant and absorption surface (Kholoud, 2010). This result demonstrates that silver nanoparticles are obtained with nanometresized.

\subsection{Phytoplankton community under AgNPs exposure}

In fact, phytoplankton communities in aquatic ecosystems are abundant and diverse with many different species and different morphologies. Qualitative analysis of the phytoplankton component in this experimental water showed that the cyanobacteria account for $90 \%$ of phytoplankton community. Microcystis genus and "water blooming" sample collected from the Tien Lake are mainly represented by species such as: $M$. aeruginosa, $M$. wesenbergii 
and $M$. ichthyoblab. Some other cyanobacteria species have also been found in the Tien Lake water samples such as: Lyngbya, Aphanocapsa, Pseudanabaena, Anabaena. In addition, some species of Bacillariophyta, Chlorophyta, Dinophyta were also recorded as: $S$. gracile, $S$. paradoxum, A. granulata, N. placentula, N. gracillis, Ceratium sp. In this study, the content of chlorophyll a and cell density were determined to assess the growth of phytoplankton communities in the lake. Based on the previous research results (Duong et al., 2016; Tran et al., 2016; Tran et al., 2015; Tran and Duong 2017), the nano silver concentration of $1 \mathrm{ppm}$ was selected for the present study. Figure 4 shows a significant difference in the growth of phytoplankton communities in the Tien Lake between control sample (no silver nanoparticles) and the sample exposure with silver nanoparticles $1 \mathrm{ppm}$. In the control sample, the initial biomass was $11.42 \pm 0.17 \mu \mathrm{g} / \mathrm{L}$ (D0) and increased slightly until the end of the experiment (D8) $12.6 \pm 1.18 \mu \mathrm{g} / \mathrm{L}$. In contrast, in the experimental sample exposed with silver nanoparticles, the biomass at the initial time (D0) was $11.27 \pm 0.56 \mu \mathrm{g} / \mathrm{L}$ and then reduced to $1.98 \pm 0.37 \mu \mathrm{g} / \mathrm{L}$ at the last day of experiment (D8).

Based on the results of cell density, we determined the effect of silver nanoparticles on the growth of both phytoplankton communities and Microcystis cyanobacteria in the Tien Lake. Figure 5 shows the variation of the phyto- plankton and the Microcystis cyanobacteria cell density in the control sample and the experimental sample. In the control sample, the cell density of phytoplankton and the Microcystis cyanobacteria did not differ significantly between the first day (D0) and the last day (D8). In contrast, after exposure to silver nanoparticles with concentration $1 \mathrm{ppm}$, in the experimental sample the total cell density decreased compared to the control samplesat the last day of experiment. These results may confirm that silver nanoparticles are capable of controlling the growth of Microcystis cyanobacteria.

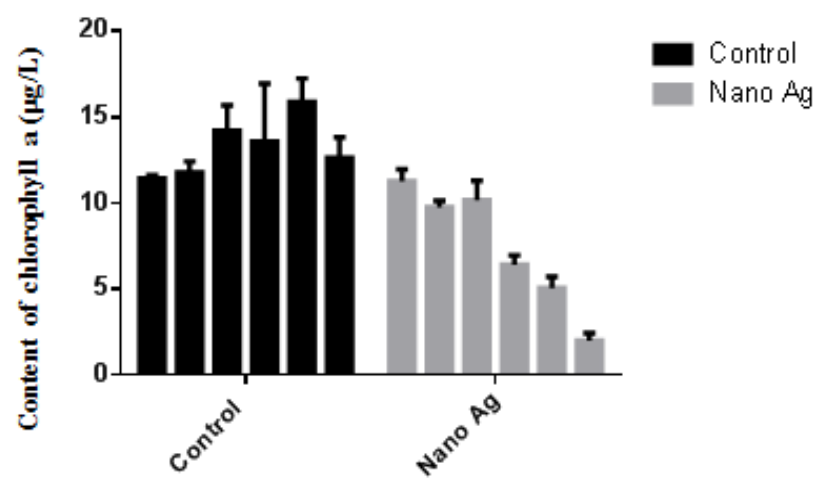

Figure 4. Variation of biomass (chla) between the control and the experimental sample were exposured with nanosilver colloids (1 ppm) after D0, D1, D2, D3, D4 and D8 days
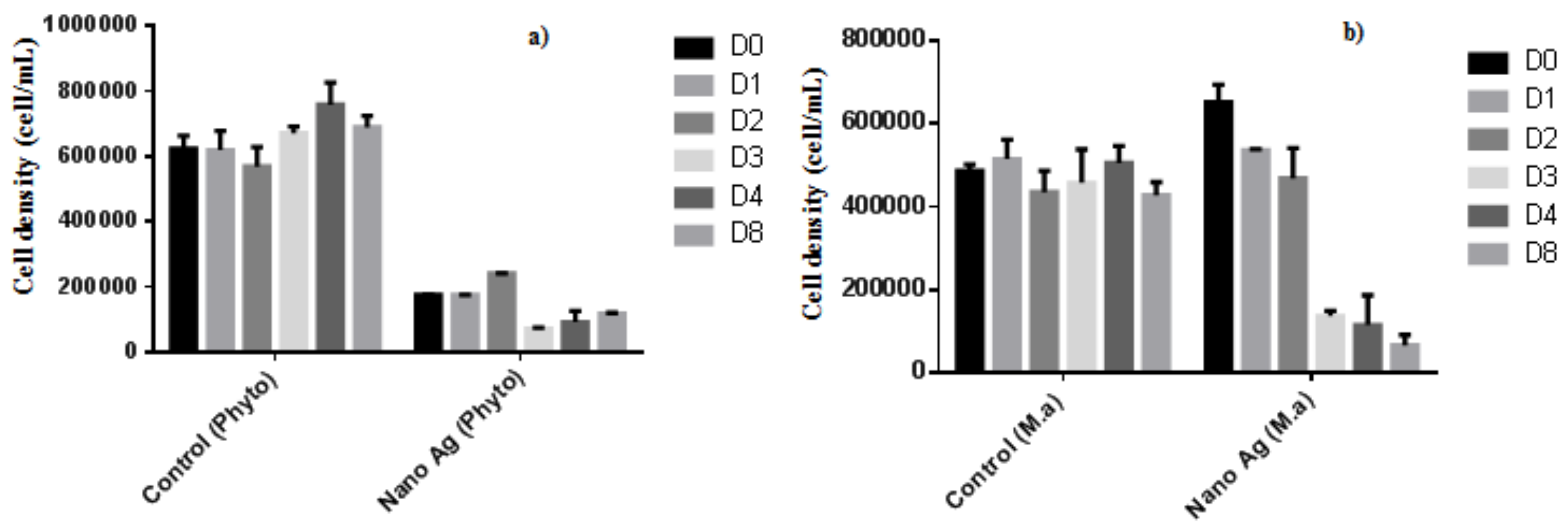

Figure 5. Variation of the cell density of phytoplankton (a) and Microcystis cyanobacteria genus (b) between the control sample and the experimental sample exposed with nanosilver colloids (1 ppm) after D0, D1, D2, D3, D4 and $\mathrm{D8}$ days

To overall assess the effect of nanomaterials on the environment when applied, in addition to biological indicators, chemical and physcical variables such as $\mathrm{pH}$, temperature, dissolved oxygen, turbidity... is also determined to assess the quality of the water environment before and after treatment with nanomaterials. Table 1 presents the average variation of the chemical and physical variables. The analysis results are showed in Table 1 .

The water temperature in the experimental sample ranged from $23.7-23.8^{0} \mathrm{C}$, which is the temperature range suitable for growth of phytoplankton and cyanobacteria. The variables such as: electrical conductivity, total dissolved solids are measured quickly by using multi-indicator devices throughout the experiment period. These values are quite stable throughout the period and varied from
22.5 to $23.6 \mu \mathrm{S} / \mathrm{cm}$ and around $0.11 \mathrm{mg} / \mathrm{L}$ respectively. The values of the $\mathrm{pH}$ and dissolved oxygen (DO) varied from 7.41 to 7.92 and 1.4 to $1.7 \mathrm{mg} / \mathrm{L}$ respectively. The value of these variables did not differ significantly between the control and the experimental samples exposed with nanosilver colloids. The Ministry of Natural Resources and Environment has issued the Vietnam standard 08:2015/MONRE: national technical standard on surface water quality, including regulations on limit values of some indicators in the receiving water sources, especially the water used for irrigation and the activities for conservation of aquatic animals and plants. According to this standard, the permissible limit values of $\mathrm{pH}$ and $\mathrm{DO}$ in the lake water are 6-8.5 and $\geq 5 \mathrm{mg} / \mathrm{L}$, respectively. The results in Table 1 show the variation in contents of ammonium and phosphorus which varied from 0.081 to 1.344 
$\mathrm{mg} \mathrm{N} / \mathrm{L}$ and 0.011 to $0.056 \mathrm{mg} \mathrm{P} / \mathrm{L}$, respectively. These values are below the limit of the Vietnam Standard
08:2015/MONRE for surface water quality.

Table 1. Variation of the chemical and physical variables in experimental samples (exposed with 1 ppm nanosilver colloids) and control samples (Tien Lake water sample without nanosilver colloids)

\begin{tabular}{lcc} 
Variables & Control sample & Experimental sample (add 1mg/L of nanosilver) \\
\hline $\mathrm{pH}$ & $8.8(8.4-9.0)$ & $7.74(7.41-7.92)$ \\
Temperature $\left({ }^{0} \mathrm{C}\right)$ & $21.4(18.8-23)$ & $23.7(23.7-23.8)$ \\
Turbidity & $139(86.6-176)$ & $80.3(40.6-180)$ \\
$\mathrm{DO}(\mathrm{mg} / \mathrm{L})$ & $1.61(1.4-1.7)$ & $1.55(1.4-1.7)$ \\
$\mathrm{Conductivity}(\mu \mathrm{S} / \mathrm{cm})$ & $19.4(18.6-19.1)$ & $23.1(22.5-23.6)$ \\
$\mathrm{TDS}(\mathrm{mg} / \mathrm{L})$ & 0.11 & 0.10 \\
$\mathrm{NH}_{4}{ }^{-}-\mathrm{N}(\mathrm{mg} / \mathrm{L})$ & $0.433(0.081-1.344)$ & $0.446(0.446-0.078)$ \\
$\mathrm{PO}_{4}{ }^{3-}-\mathrm{P}(\mathrm{mg} / \mathrm{L})$ & $0.012(0.003-0.050)$ & $0.036(0.011-0.056)$ \\
$\mathrm{Ag}(\mathrm{mg} / \mathrm{L})$ & 0 & 0.8 \\
\hline
\end{tabular}

When the application of nanoparticles is more popular, the use of nanomaterials to control "water blooming" especially to cyanobacteria has obtained some of the certain results. The work of Park et al. (2010) has demonstrated that silver nanoparticles have effected and inhibited the growth of Microcystis cyanobacteria but do not affect other algal species (Park et al., 2010). According to Blahoslav et al. (2012), the ferric nanoparticle has the ability to removebioavailable phosphorus, to destructecyanobacteria cells, immobilizemicrocystins and prevent their release into the water column (Blahoslav et al., 2012). Furthermore, toxicological studies showed that the toxicity of iron nanoparticles to $M$. aeruginosa cyanobacteria was significantly higher than other experimental organism groups such as Lemna minor, Daphnia magna, plants and fish (Blahoslav et al., 2012). In another study, Sankar et al. (2014) showed that copper oxide synthesized from plant extract is an effective bactericidal active agent. This extract is capable of controlling the flowering of $M$. aeruginosa cyanobacteria at laboratory conditions (Sankar et al., 2014).

In addition, the physical and chemical properties of nanomaterials are influenced by many other factors in the environment in which they exist such as: the ability to release and dissolve ionic particles in the environment, $\mathrm{pH}$, organic substances (humic acid), ionic intensity... (Wang et al., 2011; Huang et al., 2016). These factors can affect the antimicrobial toxicity of nanomaterials in water. Moreover, the release of metal ions from the nanoparticles is also affected by ambient environmental conditions (Wang et al., 2011). For example, the rate of metal ions released from the nanoparticles into the external environment will be limited by the organic polymers surrounding of the particles and causing the increase in water $\mathrm{pH}$ (Shamar et al., 2014; Liu et al., 2010). Huang et al. (2016) showed that humic acid reduced the toxicity of metal nanoparticles to cyanobacteria $M$. aeruginosa (Huang et al., 2016). Meanwhile, the presence of calcium and magnesium ions increased the toxicity of the metal nanoparticles for growth of these cyanobacteria species.

\section{Conclusion}

The silver nanoparticles were synthesized by chemical reduction method. The characteristic of nanomaterial was confirmed by using UV-visible spectrophotometer, TEM and HR-TEM methods. For AgNPs, their spherical form and uniform size varied from 10 to $15 \mathrm{~nm}$. The experimental results at laboratory scale show the clear effect of nanosilver colloids on inhibition of the growth and development of phytoplankton and Microcystis genus in aquarium tanks contained the Tien Lake water but no clear effect to water quality was observed. The environmental variables such as: $\mathrm{pH}$, temperature, dissolved oxygen, turbidity, ammonium, phosphate... observed during the experiment were below the limit of the Vietnam Standard 08:2015/MONRE for surface water quality. Our results provide the possibility of application of silver nanoparticles for inhibition of toxic algae in fresh waterbody in Vietnam.

Acknowledgements: This study was realized in the framework of the VAST0701/15-16 projects. The authors are grateful for the financial supports from Vietnam Academy of Science and Technology (VAST).

\section{References}

[1] Beversdorf LJ., Chaston SD., Miller TR., McMahon KD (2015) Microcystin mcyA and mcyE gene abundances are not appropriate indicators of microcystin concentrations in lakes. PLoS One, 10(5), e0125353.

[2] Marsalek B, Jancula D (2012) Multimodal action and selective toxicity of zerovalent iron nanoparticles against cyanobacteria. Environmental Science and technology 46, 2316-2323.

[3] Boopathi T., Ki JS (2014) Impact of environmental factors on the regulation of cyanotoxin production. Toxins, 6(7), 1951-1978.

[4] Codd G A (1997) Cyanobacterial blooms and toxins in fresh, brackish and marine waters, Harmful Algae. Reguera B., Blanco J., Fernandez M.L. and Wyatt T. Xuanta de galicia and Intergovemental Oceanographic Commission of UNESCO.

[5] Dang DK, Duong TT., Nguyen TTL., Dao TS., Le TPQ., Do HLC (2014) The toxic cyanobacteria in the fresh water. Science and Technology Publishing House.

[6] Drabkova M (2007) Methods for control of the cyanobacterial blooms development in lakes. $\mathrm{PhD}$ thesis, Brno, 91pp. 
[7] Drobac D., Tokodi N., Simeunović J., Baltić V., Stanić D., Svirčev Z (2013) Human exposure to cyanotoxins and their effects on health. Arh. Hig. Rada Toksikol, 64(2), 305-315.

[8] Duong TT, Le TS., Tran TTH, Nguyen TK., Ho TC., Dao TH., Le TPQ., Nguyen HC., Dang DK., Le TTH., Ha PT (2016) Inhibition effect of engineered silver nanoparticles to bloom forming cyanobacteria. Adv. Nat. Sci.: Nanosci. Nanotechnol. 7(3). doi:10.1088/2043-6262/7/3/035018.

[9] Gubbins EJ., Batty LC., Lead JR (2011) Phytotoxicity of silver nanoparticles to Lemna minor L. Environmental Pollution 159, 1551-1559.

[10] Huang T., Sui M., Yan X., Zhang X, Yuan Z (2016) Anti-algae efficacy of silver nanoparticles to Microcystis aeruginosa: Influence of NOM, divalent cations, and $\mathrm{pH}$. Colloids and Surfaces A: Physicochem. Eng. Aspects, 509, 492-503.

[11] Abou El-Nour KMM., Eftaiha A., Al-Warthan A., Ammar RAA (2010) Synthesis and applications of silver nanoparticles. Arabian Journal of Chemistry, $3,135-140$

[12] Kinidi L., Salleh S (2017) Phytoremediation of Nitrogen as Green Chemistry for Wastewater Treatment System. International Journal of Chemical Engineering, vol. 2017, article ID 1961205, 12 pages, doi.org/10.1155/2017/1961205

[13] Liu JY., Hurt RH (2010) Ion release kinetics and particle persistence in aqueous nano-silver colloids. Environ. Sci. Technol, 44, 2169-2175.

[14] Kumar MNVR (2000) A review of chitin and chitosan aplications. Reactive and Functional Polymers, 46(1), 1-27.

[15] Sikder M., Lead JR., G., Chandler, T., Baalousha M (2017) A rapid approach for measuring silver nanoparticle concentration and dissolution in seawater by UV-VIS. Sci Total Environ. 618, 597-607, doi: 10.1016/j.scitotenv.2017.04.055.

[16] Siwach OP., Sen P (2008) Fluorescence properties of Ag nanoparticles in water. Spectrochimica Acta Part A, 69, 659-663.

[17] Paerl, H.W (2014) Mitigating harmful cyanobacterial blooms in a human-and climatically-impacted world. Life, 4(4), 988-1012.

[18] Park M.H., Kim K.H., Lee H.H., Kim J.S., Hwang S.J (2010) Selective inhibitory potential of silver nanoparticles on the harmful cyanobacterium Micro- cystis aeruginosa. Biotechnol Lett, 32(3), 423-428.

[19] Sankar R., Prasath BB., Nandakumar R., Santhanam P., Shivashangari SK., Ravikumar V (2014) Growth inhibition of bloom forming cyanobacterium Microcystis aeruginosa by green route fabricated copper oxide nanoparticles. Environ Sci Pollut Res, 21, 14232-14240.

[20] Smith V (1983) Low nitrogen to phosphorus ratios favour dominance by blue green algae in lake phytoplankton. Science 221, 699-671.

[21] Prabhu S., Poulose EK (2012) Silver nanoparticles: mechanism of antimicrobial action, synthesis, medical applications and toxicity effects. International Nano Letters, 2, 32.

[22] Sharma S., Choudhary K., Sighal I., Saini R (2014) Synthesis of Silver Nanoparticles by 'Electrochemical Route' through pure metallic Silver electrodes, and evaluation of their Antimicrobial Activities. Int. J. Pharm. Sci. Rev. Res, 28(2), 272-277.

[23] Tran THH., Duong TT., Ha PT., Nguyen TK., Dang DK., Dao TH (2016) The initial results for investigating effects of nanomaterials on growth and development of cyanobacterial population on Microcystis aeruginosa. ISBN 978-604-913-088-5, 65-79.

[24] Tran TTH., Duong TT., Nguyen TK., Ho TC., Dang DK., Ha PT., Dao TJ., Nguyen HC., Le TPQ., Dinh THV., Trinh QH (2015) The effect of nanoparticles on growth of cyanobacteria strain Microcystis aeruginosa. Journal of Science and Technology 53 (3A), 50-57.

[25] Tran TTH., Duong TT (2017) Chlorella vulgaris Green Algae under the Affection of Silver Nanomaterial. VNU Journal of Science: Natural Sciences and Technology, 33(1S), 1-3.

[26] Tran TTH., Nguyen TK., Nguyen TTT., Ha PT., Le TPQ., Do VB., Dinh THV., Trinh QH., Duong TT (2016) Nanoparticles as a control for cyanobacterial bloom. J. Viet. Env. 8(3), 161-166.

[27] Wang Z., Li J,, Zhao J., Xing B (2011) Toxicity and Internalization of $\mathrm{CuO}$ Nanoparticles to Prokaryotic Alga Microcystis aeruginosa as Affected by Dissolved Organic Matter. Environ. Sci. Technol, 45, 6032-6040.

[28] Wang H., Dai M., Liu J., Kao SJ., Zhang C., Cai U’, Wang G., Qian U., Zhao M., Sun Z (2016) Eutrophication-driven hypoxia in the East China Sea off the Changjiang Estuary. Environ. Sci. Technol, 50(5), 2255-2263. 